\title{
Pengaruh Hafalan Ayat AL-Qur'an terhadap Prestasi Belajar Siswa Mata Pelajaran Al-Qur'an Hadits Di Madrasah Ibtidaiyah Al-Azhar Serabi Barat Bangkalan
}

\author{
1. Subhan Adi Santoso, 2. Himmatul Husniyah, 3. Umar Faruq \\ Sekolah Tinggi Ilmu Tarbiyah Muhammadiyah Paciran Lamongan, Indonesia \\ subhan.stitm@gmail.com,himmatulhusniyah11@gmail.com,umarfaruq@gmail.com
}

\begin{abstract}
: education is a basic necessity for every human being, because with the education that human beings can determine the next steps.

In this study the authors use a method of survey with a correlation approach conducted in Madrasah Ibtidaiyah Al-Azhar Serabi Barat Bangkalan by involving class III, IV, V and VI students who participated in the memorization activities of the Qur'an. Data collection is done with observations, polls, and documentaries. Data analysis using correlation analysis with product moment formula correlation technique.

The results of the research obtained to answer the formulation of problems are: 1) the application of memorization of the Qur'an in Madrasah Ibtidaiyah Al-Azhar Serabi Barat Bangkalan applied according to the results of observation and based on the results of the poll, hence the result obtained is 55.5. Thus, the average score number of the memorization rate of Al-Quran Madrasah Ibtidaiyah Al-Azhar Serabi Barat Bangkalan is good enough, 2) Student learning achievement on the subjects of the Qur'an hadith in Madrasah Ibtidaiyah Al-Azhar Serabi Barat Bangkalan after the memorization activities of the Qur'an is in good category with an average of 81.92 of the entire respondent, and 3) the influence between memorization of Al-Qur'an with students ' learning achievement in the field of Quranic study in Madrasah Ibtidaiyah AlAzhar Serabi Barat Bangkalan with medium interpretation. With the correlation number between variable $X$ and variable $Y$ of 0511. Its significance by 5\% seen from table Correlation Product Moment.
\end{abstract}

Keywords: Memorization of Al-Qur'an Verses, Student Learning Achievement

\section{Pendahuluan}

Pendidikan merupakan kebutuhan pokok bagi setiap manusia, karena dengan pendidikan yang diperoleh manusia bisa menentukan langkah-langkah selanjutnya. Melalui pendidikan ini manusia dapat merancang masa depannya. Dengan pendidikan manusia bisa menentukan mana yang baik dan mana yang buruk, sehingga dalam menentukan sikap dan tingkah laku dapat berjalan di atas kebenaran yang telah dilayani sebagaimana didapatkan ketika mereka belajar. Pen-didikan selain merupakan alat bagi 
tercapainya tujuan hidup bangsa agar menjadi bangsa yang sejahtera, juga merupakan suatu cara untuk mengubah keadaan bangsa itu sendiri.

Pendidikan juga merupakan suatu proses penyiapan generasi muda untuk menjalankan kehidupan dan memenuhi tujuan hidupnya secara lebih efektif dan efisien (Azyumardi Azra, 2002, p.3). Bukan sekedar pengajaran, melainkan dapat dikatan sebagai suatu proses transfer ilmu, bukan transformasi nilai, dan pemben-tukan kepribadian dengan segala aspek yang dicakupnya.

Pendidikan Islam merupakan suatu usaha yang sistematis dan pragmatis dalam membimbing anak didik yang beragama Islam untuk benar-benar menjiwai dan menjadikannya sebagai bahan yang integral serta sebagai pedoman dalam hidupnya sehingga dapat dijadikan sebagai alat pengontrol bagi perbuatan-perbuatannya, pemikiran,dan sikap mentalnya. Sehingga anak didik nanti diharap-kan memiliki keseimbangan antara kepandaian secara intelektual dan agamis, da-pat membimbing dirinya sendiri untuk selalu bertindak dan berperilaku secara so-pan dan santun, dan mengarahkan keluarganya nanti agar terhindar dari siksa api neraka.

Berbicara tentang Pendidikan Islam atau pendidikan Qur'ani, pada dasarnya tidak bisa lepas dari membicarakan tujuan hidup manusia dalam Islam; yaitu untuk menciptakan pribadi-pribadi hamba Allah yang selalu bertaqwa kepa-daNya dan mencapai kehidupan yang berbahagia di dunia dan akhirat (Azyumardi Azra, 2002, p.8).

Pendidikan Al-Qur'an merupakan pendidikan dasar yang sangat penting bagi seorang muslim disamping pendidikan Akhlaq. Karena dengan dasar pen-didikan AlQur'an dan Sunnah dari Rasulullah, diharapkan seorang anak dapat hidup berkembang dengan menjiwai Al-Qur'an dan Sunnah Rasul dalam setiap sendi kehidupannya.Sehingga, ia dapat berkembang menjadi manusia yang memi-liki kecerdasan dalam iptek dan kecakapan dalam imtaq. Oleh karena itu, pada masa ini sedang dikembangkan tentang pendidikan yang kembali kepada Al-Qur'an. Banyak sekolah-sekolah baik dari tingkat dasar sampai tingkat menengah bahkan sampai perguruan tinggi yang mengembangkan pendidikan yang berbasis pada Al-Qur'an dan Hadits, karena hanya dengan kembali kepada ajaran Al-Qur'an dan Hadits pendidikan akan menemukan jalan terang. 
Pendidikan Al-Qur'an juga berkeyakinan bahwa tujuan yang benar dari pendidikan adalah melahirkan manusia-manusia yang beriman dan berilmu pengetahuan, yang dari imannya itu akan melahirkan tingkah laku terpuji akhlakul karimah, karena pengetahuan yang dipisahkan dari iman bukan hanya akan men-jadi pengetahuan yang pincang akan tetapi lebih dari itu ia dapat memberikan suatu kebodohan baru, sehingga manusia telah kehilangan keimanannya kepada Tuhan, betapapun luasnya pengetahuan yang dimiliki menurut Islam ia baru me-miliki dan memperoleh satu sisi pandangan yang tidak lengkap tentang alam raya ini sebagaimana hadits berikut (Al Mundziri, 2003):

Artinya: Sesungguhnya Allah, dengan kitab ini (Al Qur'an) meninggikan derajat kaum-kaum dan menjatuhkan derajat kaum yang lain (HR. Muslim).

Melihat betapa pentingnya pendidikan Al-Qur'an, maka diharapkan pem-berian pendidikan ini dimulai dari sejak dini dan dari lingkup yang paling kecil yaitu dalam lingkungan keluarga. Keluarga adalah lingkungan pertama yang paling esensial dalam memberikan pendidikan dini kepada anak. Rasulullah Muhammad saw. memerintahkan kepada umatnya agar mengajari anak-anaknya untuk mencintai kepada Nabi mereka, mencintai keluarganya ahli baitnya, para sahabat, dan cinta untuk membaca Al-Qur'an. Hal ini sesuai denga sabda Nabi Muhammad saw. yang diriwayatkan oleh Ath-Thabrani yang artinya:

Artinya: Didiklah anak-anakmu pada tiga perkara: Cinta kepada Nabi kamu, cinta kepada ahli baitnya, dan membaca Al-Qur'an.

Pendidikan awal yang diterima seorang anak akan memberikan dampak yang sangat nyata terhadap perkembangan anak pada tahap pendidikan selanjut-nya, yaitu ketika anak sudah belajar di bangku sekolah. Selain itu, pendidikan hafalan Al-Qur'an yang dimulai sejak dini akan lebih mudah dan berpengaruh positif terhadap perkembangan kepribadian anak, kemampuan berfikir anak, dan keterampilan anak dalam meraih prestasi belajar anak tersebut dikarenakan pikiran anak masih bersih dan ingatannya masih kuat. Salah satu pembelajaran Al-Qur'an yang dimulai sejak dini 
adalah Tahfidzul Qur'an, yaitu proses mempelajari Al-Qur'an dengan cara menghafalkan ayat-ayat Al-Qur'an.

Untuk menjadikan muslim yang sejati, beriman tangguh, beramal sholeh dan berakhlak mulia tidaklah mudah semua itu membutuhkan pembiasaan yang intensif. Kebanyakan lembaga pendidikan maupun sekolah merasa berhasil dan sukses mencapai tujuan pendidikan dengan menjalankan proses belajar mengajar sesuai dengan kurikulum yang menjadi pedoman. Secara akademik, banyak yang merasa berhasil dalam menuntaskan pendidikannya tapi apakah mereka sudah yakin anak didiknya mampu bersikap dengan baik dan benar ketika berdiri di tengah-tengah masyarakat? Hal itulah yang menjadi harapan kita semua baik dari pihak Orang tua maupun pendidik dalam suatu lembaga pendidikan.

Melihat fenomena itu, usaha yang dilakukan lembaga pendidikan Madra-sah Ibtidaiyah Al-Azhar Serabi Barat Bangkalan adalah berusaha mencetak lulu-san yang sukses atau berhasil dalam aspek akademik maupun non akademik. Ba-nyak sekali faktor yang dapat mempengaruhi keberhasilan tersebut, salah satunya adalah membiasakan anak didiknya berakhlak dan berfikir secara Qur'ani. Yang mana di sini guru mata pelajaran Al-Qur'an Hadits menerapkan metode hafalan Al-Qur'an. Dengan diselengarakannya program tersebut diharapkan anak didik dapat meng-ikuti dengan baik sebagai penunjang dalam bidang studi Al-Qur'an Hadits dan Akhlak sehingga hasil belajar atau prestasi dalam bidang studi tersebut bisa meningkat dengan adanya program hafalan Al-Qur'an dan juga diimplemen-tasikan dalam kehidupan sehari-hari baik dalam lingkungan lembaga pendidikan maupun lingkup masyarakat.

Dari latar belakang tersebut maka penulis tertarik untuk meneliti bagai-mana Pengaruh Hafalan Ayat AL-Qur'an terhadap Prestasi Belajar Siswa Bi-dang Studi AlQur'an Hadits Di Madrasah Ibtidaiyah Al-Azhar Serabi Barat Bangkalan.

\section{Rumusan Masalah}

Berdasarkan uraian yang terdapat dalam latar belakang masalah di atas, maka penulis tuliskan rumusan masalahnya adalah sebagai berikut: 
1. Apakah ada pengaruh hafalan ayat Al-Qur'an terhadap prestasi belajar siswa mata pelajaran Al-Qur'an Hadits di Madrasah Ibtidaiyah Al-Azhar Serabi Barat Bangkalan?

2. Bagaimana prestasi belajar mata pelajaran Al-Qur'an Hadits siswa Madrasah Ibtidaiyah Al-Azhar Serabi Barat Bangkalan?

\section{Hipotesis Penelitian}

Hipotesa yang dapat diajukan dalam penelitian ini sebagai berikut:

1. Hipotesa Alternatif (Ha)

ada pengaruh positif antara Hafalan ayat Al-Qur'an dengan prestasi belajar siswa bidang studi Al-Qur'an Hadits di Madrasah Ibtidaiyah Al-Azhar Serabi Barat Bangkalan.

2. Hipotesa Nihil (Ho)

Tidak ada pengaruh positif antara Hafalan ayat Al-Qur'an dengan prestasi belajar siswa bidang studi Al-Qur'an Hadits di Madrasah Ibtidaiyah Al-Azhar Serabi Barat Bangkalan.

\section{Landasan Teori}

\section{Pengertian Hafalan Al Qur'an}

Kata Tahfidz berasal dari bahasa arab
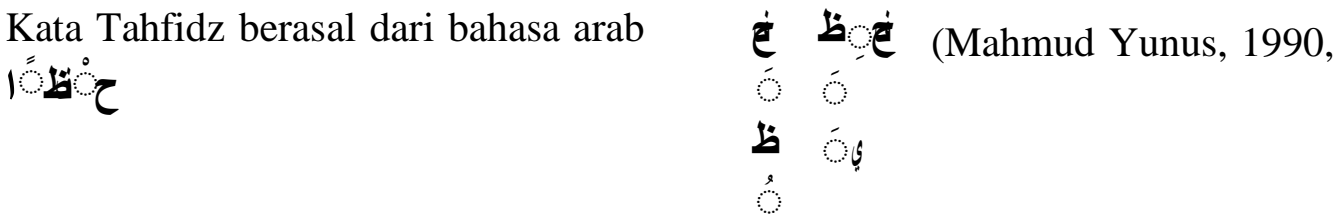

p.105) yang artinya memelihara, menjaga dan menghafal. Tahfidz secara bahasa (etimologi) adalah lawan dari lupa, yaitu selalu ingat dan sedikit lupa. Dalam kamus besar bahasa Indonesia disebutkan bahwa kata hafal berarti telah masuk dalam ingatan (tentang pelajaran). Dan dapat mengucapkan kembali di luar kepala (tanpa melihat buku). Menghafal (kata kerja) berarti berusaha meresapkan ke dalam pikiran agar selalu ingat. (Departemen Pendidikan nasional, 2008)

Tahfidz adalah bentuk masdar dari haffadza yang memiliki arti penghafalan dan bermakna proses mengafal. Sebagaimana lazimnya suatu proses menulis suatu 
tahapan, teknik atau metode tertentu. Tahfidz adalah proses menghafal sesuatu ke dalam ingatan sehingga dapat diucapkan di luar kepala dengan metode tertentu.

Secara istilah menurut Abdur robi Nawabudin, hafal mengandug dua po-kok, yaitu hafal seluruh Al-Qur'an serta mencocokannya dengan sempurna dan senantiasa terus menerus dan sungguh-sungguh dalam menjaga hafalan dari lupa (Fifi Lutfiah, 2011, p.22).

Dalam hal ini menghafal Al-Qur'an memeliharannya serta menalarnya haruslah memperhatikan beberapa unsur pokok sebagai berikut:

a. Menghayati bentuk-bentuk visual, sehingga bisa diingat kembali meski tan-pa kitab.

b. Membaca secara rutin yang dihafalkan.

c. Penghafal Al-Qur'an dituntut untuk menghafal secara keseluruhan baik hafalan maupun ketelitian.

d. Menekuni, merutinkan dan menjaga hafalan dari kelupaan.

Sedang pengertian Al-Qur'an (القرآن berasal dari bahasa Arab dari kata kerja fi'il yang artinya adalah membaca. Sedangkan menurut Muhammad Ab-dullah dalam kitabnya, Kaifa Tahfadzul Qur'an, memberi definisi Al-Qur'an sebagai berikut, AlQur'an adalah Kalam Allah yang diturunkan kepada Nabi Muhammad melalui perantara Ruuhul Amin (Malaikat Jibril) dan dinukilkan kepa-da kita dengan tawatur yang membacanya dinilai sebagai ibadah, diawali dengan surat Al-Fatihah dan diakhiri dengan surat An-Naas (Fifi Lutfiah, 2011, p.18).

Dari definisi di atas, maka Kalam Allah yang diturunkan kepada selain Nabi Muhammad SAW seperti: Taurat, Zabur, Injil, dan shuhuf Ibrohim tidak dinamakan Al-Qur'an. Demikian halnya dengan firman Allah yang diturunkan kepada Nabi Muhammad SAW akan tetapi tidak dimasukkan ke dalam mushhaf, juga tidak dinamakan Al-Qur'an, tapi disebut Hadits Qudsi.

Jadi menghafal Al-Qur'an adalah proses penghafalan Al-Qur'an secara keseluruhan, baik hafalan maupun ketelitian bacaannya serta menekuni, merutin-kan dan mencurahkan perhatiannya untuk melindungi hafalan dari kelupaan. Se-dangkan 
hafalan Al-Qur'an yang dimaksud dalam skripsi ini adalah hanya proses hafalan AlQur'an pada juz 30 saja.

Dengan demikian dapat diketahui bahwa hakikat dari hafalan adalah ber-tumpu pada ingatan.Berapa lama waktu untuk menerima respon, menyimpan, dan memproduksi kembali tergantung ingatan masing-masing pribadi. Karena kekua-tan ingatan seseorang berbeda-beda.

\section{Hukum Hafalan Al Qur'an}

Al-Qur'an adalah kitab suci bagi pemeluk agama Islam, sebagai pedoman hidup dan sumber-sumber hukum, tidak semua manusia sanggup menghafal dan tidak semua kitab suci dapat di hafal kecuali kitab suci Al-Qur'an dan hamba-hamba yang terpilih yang sanggup menghafalnya. Hal ini dibuktikan dalam firman Allah SWT:

Artinya: Kemudian kitab itu Kami wariskan kepada orang-orang yang Kami pilih di antara hamba-hamba Kami (Qs. Al-Fatir: 32).

Ayat di atas menunjukkan bahwa Al-Qur'an diturunkan secara hafalan lisan bukan dengan tulisan, setelah Nabi Muhammad SAW menerima bacaan dari Malaikat Jibril AS, Nabi dilarang mendahuluinya agar supaya Nabi lebih mantap hafalanya. Oleh karena itu, sebagai dasar bagi orang-orang yang akan menghafal AlQur'an adalah :

a. Al-Qur'an itu diturunkan dengan hafalan

b. Mengikuti Nabi Muhammad SAW

c. Melaksanakan anjuran Nabi Muhammad SAW

Dalam arti bahwa umat Islam harus ada bukan harus banyak yang hafal AlQur'an mengikuti Nabi Muhammad SAW untuk menjaga nilai mutawatir. Apabila hal ini tidak dilakukan maka seluruh umat Islam menanggung dosa, dan ketetapan hukum seperti itu tidak berlaku pada kitab-kitab samawi yang lain.

Dengan demikian jelaslah bahwa menghafal Al-Qur'an hukumnya adalah fardhu kifayah. Fardhu kifayah sebagaimana yang dimaksud ulama yaitu apabila suatu pekerjaan disuatu wilayah tidak ada yang mengerjakanmaka semua orang yang 
ada di wilayah tersebut kena (berdosa) semua. Karena tidak melakukan perbuatan tersebut.

\section{Syarat-Syarat dan Etika Menghafal Al-Qur'an}

Menghafal Al-Qur'an bukan merupakan suatu ketentuan hukum yang haru dilakukan orang yang memeluk agama islam. Oleh karena itu menghafal Al-Qur'-an tidak memiliki syarat-syarat yang mengikat sebagai ketentuan hukum. Syarat-syarat yang harus dimiliki oleh seorangcalon penghafal Al-Qu'an adalah syarat-syarat yang berhubungan dengan naluri insaniyah semata. Syarat-syarat tersebut sebagai berikut:

a. Niat yang ikhlas

"Sesungguhnya amal-amal perbuatan tergantung niatnya, dan bagi tiap orang apa yang diniatinya. Barangsiapa hijrahnya kepada Allah dan Rasul-Nya maka hijrahnya kepada Allah dan Rasul-Nya. Barangsiapa hijrahnya untuk meraih kesenangan dunia atau menikahi wanita, maka hijrahnya ada-lah kepada apa yang ia hijrahi" (HR. Bukhari)

Niat ikhlas dalam menghafal Al-Qur'an harus dipertahankan secara isti-qomah. Hal ini akan menjadi motivator yang sangat kuat untuk mencapai kesuksesan dalam menghafalkan Al-Qur'an.

b. Menjauhi sifat madzmumah

Sifat madzmumah adalah suatu sifat tercela yang harus dijauhi oleh setiap orang muslim, terutama di dalam menghafal Al-Qur'an. Karena sifat madz-mumah ini sangat besar pengaruhnya terhadap orang-orang penghafal Al-Qur'an.

Diantara sifat-sifat yang harus dijauhi seorang anak yang menghafal Al-Qur'an adalah khianat, bakhil, pemarah, memencilkan diri dari pergaulan, iri hati, sombong, dusta, ingkar, riya', banyak makan, meremekan orang lain dan lain sebagainya.

Sifat-sifat tercela di atas mempunyai pengaruh besar terhadap perkemba-ngan jiwa dan mengusik ketenangan hati anak yang sedang dalam proses menghafalkan Al-Qur'an. Baik pengaruh dari lingkungan keluarga, sekolah maupun masyarakat. 
c. Motivasi dan dukungan orang tua

Motivasi atau dukungan orang tua sangat penting bagi anak dalam meng-hafalkan Al-Qur'an karena menjadi penyemangat untuk mencapai keberha-silannya.

d. Memiliki keteguhan dan kesabaran

Dalam proses menghafal Al-Qur'an akan banyak sekali ditemui berbagai macam kendala yang bisa berupa jenuh atau bosan, gangguan lingkungan, gangguan batin atau tidak tenangnya pikiran dan lain sebagainya. Terutama dalam menjaga kelestarian Al-Qur'an. Sebagaimana sabda Nabi Muham-mad yang artinya:

"sesungguhnya perumpamaan orang yang menghafal Al-Qur'an itu sepert perumpamaan orang yang memiliki seekor unta yang sedang ditambatkan. Jika ia ingin untanya itu tetap ditempat, maka ia harus menjaga dan menahannya, dan kalau sampai dilepas maka unta itu akan lari." ( HR. Bukhori-Muslim)

Untuk melestarikan hafalan Al-Qur'an perlu keteguhan dan kesabaran. Karna kunci utama keberhasilan menghafal Al-Qur'an adalah ketekunan menghafal dan mengulang ayat yang dihafalkan.

e. Istiqomah

Yang dimaksud disini adalah konsisten terhadap hafalannya. Seorang penghafal Al-Qur'an harus senantiasa menjaga efisiensi waktu, berarti se-orang penghafal akan menghargai waktu dimanapun dan kapanpun saja ada waktu luang.

Nabi Muhammad SAW bersabda yang artinya:

"Barang siapa yang selalu disibukkan dengan membaca Al-Qur'an dan dzikir kepada-Ku, maka ia akan $\mathrm{Ku}$ beri anugerah yang baik, yang diberikan kepada oranr-orang yang memohon kepadaKu."(HR. Tirmidhi dan Al-Baihaqi)

Sang penghafal dianjurkan memiliki waktu-waktu khusus, baik untuk menghafal materi baru maupun untuk mengulang bacaan yang di hafal mu-roja'ah, agar selalu ingat atas apa yang dihafalkannya.

\section{Metode Menghafal Al-Qur'an}

banyak sekali metode-metode yang mungkin bias dikembangkan dalam rangka mencari alternatif terbaik untuk menghafalkan Al-Qur'an. Dan bisa mem-berikan 
bantuan kepada para penghafal dan mengurangi kepayahannya menghafal Al-Qur'an, metode-metode tersebut adalah:

a. Metode Wahdah

Metode ini digunakan dengan cara menghafal satu persatu ayat-ayat yang hendak di hafalnya. Untuk mencapai hafalan awal, setiap ayat biasa dibaca sebanyak sepuluh kali atau duapuluh kali bahkan lebih, Sehingga mampu membentuk pola pada bayangannya. Setelah benar-benar hafal barulah di-lanjutkan pada ayat-ayat berikutnya

Dengan cara yang sama, demikian seterusnya sehingga mencapai satu muka. Setelah ayat-ayat dalam satu muka sudah hafal barulah menghafal urutan-urutan ayat dalam satu muka.

b. Metode Kitabah

Kitabah adalah menulis. pada metode ini penghafal terlebih dulu menulis ayatayat yang akan dihafalnya pada selembar kertas yang telag disiapkan. Kemudian ayat tersebut dibacanya sehingga lancer dan benar bacaannya, lalu di hafalkan.

c. Metode Sama'i

Sima'I adalah mendengar. Yaitu mendengarkan suatu bacaan untuk diha-falkan. Metode ini sangat efektif bagi penghafal tuna netra atau anak-anak yang masih kecil dibawah umur yang belum mengenal tulis baca Al-Qur'-an. Metode ini dilakukan dengan dua alternatif:

1) Mendengarkan dari guru yang membimbingnya, terutama bagi penghafal tuna netra dan anak-anak.

2) Merekam terlebih dahulu ayat-ayat yang akan dihafalkan menggunakan alat perekam suara sesuai dengan kebutuhan dan kemampuannya.

d. Metode Gabungan

Metode ini adalah gabungan antara metode wahdah dan kitabah yakni peng-hafal menghafalkan ayat-ayat sampai hafal betul. Kemudian setalah itu penghafal mencoba menulis ayat yang sudah dihafalnya di atas kertas. Jika mampu menulis kembali ayat-ayat yang dihafalnya maka bisa melanjutkan ayat selanjutnya. 
e. Metode jama'

yaitu cara menghafal yang dilakukan secara kolektif, yakni ayat yang di-hafal dibaca secara bersama-sama dipimpin oleh guru pembimbing. Pertama guru pembimbing menbacakan ayat Al-Qur'an dan siswa menirukan secara bersamasama.

\section{Prestasi Belajar}

\section{Pengertian Prestasi Belajar}

Dilihat dari penyusun katanya, prestasi belajar berasal dari dua kata, yakni “prestasi”, dan "belajar". Meskipun dua kata ini acap kali berdampingan, dan bahkan selalu dijumpai berdampingan, namun para pakar menjelaskan dua kata ini dalam definisi yang terpisah. Djamarat menjelaskan bahwa prestasi adalah hasil dari suatu kegiatan yang telah dikerjakan, dilakukan, baik secara individual maupun kelompok (Syaiful Bahri Djamarat, 1994, p.19). Menurut Russfendi, prestasi berasal dari bahasa belanda yaitu prestatie, kemudian dalam bahasa indonesia menjadi prestasi yang berarti hasil usaha. Prestasi adalah kemampuan, ketrampilan dan sikap seseorang dalam menyelesaikan sesuatu (Russefendi,1991, p.289). Jadi prestasi seseorang akan sangat berhubungan dan dipengaruhi oleh seberapa besar usaha yang ia lakukan untuk memperolehnya.

Sedangkan belajar itu sendiri memiliki beberapa pengertian yang disampaikan oleh beberapa ahli, diantaranya adalah: M. Dalyono, beliau mendefinisikan belajar sebagai usaha atau kegiatan yang bertujuan mengadakan perubahan dalam diri seseorang, yang mencakup perubahan tingkah laku, sikap, kebiasaan, ilmu pengetahuan, keterampilan, dan lain sebagainya (Nana Syaodih Sukmadinata, 2011, p.78). Witheringon, dalam buku Education Psychology, mengatakan bahwa belajar adalah suatu perubahan di dalam kepribadian yang menyatakan diri sebagai suatu pola baru dari pada reaksi yang berupa kecakapan, sikap, kebiasaan, kepandaian, atau suatu pengertian (M. Ngalim Purwanto, 2006, p.84).

Berdasarkan definisi dari dua kata di atas, dapat kita simpulkan bahwasannya prestasi belajar akan sangat dipengaruhi oleh seberapa besar usaha seseorang untuk mencapai prestasi belajar yang gemilang (Subhan Adi Santoso, 2020, p.163). 
"Belajar adalah suatu bentuk perubahan dalam diri seseorang yang dinyatakan dalam cara-cara bertingkah laku yang baru berkat pengalaman dan latihan. Tingkah laku yang baru itu misalnya dari tidak tahu menjadi tahu. Timbul pengertian baru,timbul dan berkembangnya sifat-sifat sosial dan emosional". (Ahmad, Abu dan Widodoh, Supriyadi, 1990, p.127) "Sementara itu Hilgard, memberi definisi belajar sebagai berikut : Learning is the process by which an activity originates or is changed through training procedures weather is the laboratory or in the natural environment as distinguished from changes by factory not atribut to training" (Ahmad, Abu dan Widodoh, Supriyadi, 1990, p.132).

Dalam definisi ini dikatakan bahwa seseorang yang belajar adalah merupakan suatu proses aktif dalam memperoleh pengalaman atau pengetahuan baru sehingga menyebabkan perubahan tingkah laku.

Belajar pada dasarnya merupakan suatu proses, artinya kegiatan belajar senantiasa dinamis dan mengarah kepada terjadinya perubahan dalam diri pembelajar. Dalam hal ini Pasaribu melukiskan belajar sebagai suatu proses perubahan kegiatan, reaksi terhadap lingkungan (Simanjuntak dan Pasaribu, 1992, p.73). Ada banyak faktor yang mendorong terjadinya proses belajar yang efektif, antara lain, motivasi, kualitas dan kuantitas perhatian selama belajar, kemampuan menerima dan mengingat, kemampuan menerapkan belajar pada situasi baru yang dihadapi, kemampuan mendemonstrasikannya (Subhan Adi Santoso, 2020, p.163).

Begitu juga dengan Djamarah, yang mengemukakan bahwa prestasi belajar adalah hasil yang diperoleh berupa kesan-kesan yang mengakibatkan perubahan dalam diri individu sebagai hasil dari aktifitas belajar (Djamarah, Syaiful, B, 1984, p.103). Konsep prestasi belajar seperti diatas merupakan arti secara umum. Dalam kaitannya dengan sejauh mana tingkat kemampuan siswa menguasai pelajaran yang telah diajarkan kepadanya. Dari pendapat para ahli ini dapat diberikan dua ciri-ciri belajar, yaitu: a) terjadinya interaksi, b) adanya tingkah laku baru sebagai hasil interaksi. Dan tingkah laku yang baru itulah yang pada umumnya disebut sebagai prestasi belajar. Dengan demikian sebagai prestasi belajar seorang siswa adalah perubahan perilaku siswa (pengetahuan, sikap dan atau keterampilan) sebagai hasil 
dari interaksi dengan para guru di sekolah. Dalam kaitannya dengan perubahan perilaku siswa sebagai hasil belajar ini, Gagne dan Grounlound membagi ke dalam lima ragam belajar, yaitu:

a. Informasi verbal

b. Keterampilan intelektual

c. Keterampilan motorik

d. Sikap

e. Siasat kognitif . (Gagne, Robert, M., 1983, p.247)

Prestasi belajar yang diharapkan setelah siswa mengikuti program pendidikan atau proses belajar mengajar adalah adanya perubahan perilaku siswa mengenai pengetahuan, sikap dan perilaku serta keterampilan yang dicapai selama selang waktu tertentu. Hal ini sejalan dengan pandangan yang dikemukakan oleh Bloom tentang tiga taksonomi ranah prestasi belajar, yang dikemukakan oleh Sudjana yaitu:

a. Ranah kognitif, meliputi: 1) ingatan, 2) pemahaman, 3) aplikasi, 4) sintesis, 5) evaluasi.

b. Ranah afektif, meliputi: 1) penerimaan, 2) jawaban atau reaksi, 3) penilaian, 4) organisasi, 5) Internalisasi.

c. Ranah psikomotorik, meliputi: 1) gerakan refleks, 2) keterampilan gerakan dasar, 3) kemampuan perseptual, 4) keharmonisan dan ketetapan, 5) gerakan berupa keterampilan-keterampilan yang bersifat kompleks, 6) gerakan ekspresif dan interprelatif. (Sudjanah, 1992, p.28)

Bertolak dari pengertian tersebut prestasi belajar mempunyai peran yang sangat penting dalam pendidikan, bahkan kualitas pendidikan dicerminkan antara lain oleh siswa pada mata pelajaran yang telah dipelajari di sekolah. Sejalan dengan beberapa pengertian tersebut, pengertian menekankan pada hasil yang dicapai dari suatu kegiatan atau aktifitas. Prestasi belajar adalah suatu hasil pendidikan yang diperoleh siswa setelah melewati proses pendidikan dalam jangka waktu tertentu.

Sebagai kesimpulan dari hal tersebut prestasi belajar adalah kemampuan yang diperolah siswa setelah ia melakukan proses belajar baik dalam bedang studi tertentu maupun dalam suatu cakupan kurikulum sekolah dengan menggunakan tes standar 
sebagai alat untuk mengetahui adanya perubahan dalam aspek kecakapan, tingkah laku dan keterampilan.

\section{Faktor Yang Mempengaruhi Prestasi Belajar}

Tingkat prestasi belajar yang dicapai oleh siswa tidak tumbuh dan berkembang begitu saja, tetapi merupakan suatu hasil interaksi dari berbagai faktor yang mempengaruhi, baik yang bersifat internal maupun yang bersifat eksternal.

Slameto membagi faktor-faktor yang menentukan prestasi belajar atas faktor eksternal, yakni keadaan di luar diri siswa yang meliputi; kondisi keluarga, sekolah, dan masyarakat. Dan faktor internal yakni keadaan dari diri siswa yang meliputi keadaan fisik dan psikologi termasuk kelelahan baik fisik maupun psikis. (Slameto, 1991, p.72)

Dalam kaitannya dengan faktor internal, kondisi psikologi memiliki peranan yang penting mengingat belajar itu sendiri merupakan proses mental yang kompleks. Suryabrata mengemukakan bahwa faktor psikologis yang berpengaruh terhadap prestasi belajar siswa meliputi minat, kecerdasan, bakat, motivasi dan kemampuan kognitif. (Suryobrota Sumadi, 1990, p.164)

Berdasarkan penjelasan tersebut di atas, tampak bahwa faktor-faktor yang menentukan prestasi belajar adalah sangat beragam. Karena begitu beragamnya faktor yang menentukan tinggi rendahnya prestasi belajar siswa, maka hal penting untuk diupayakan adalah mengelola berbagai faktor dalam artian menompang dan memperlancar usaha belajar siswa agar mencapai prestasi belajar yang diinginkan.

Maka dapat disimpulkan bahwa prestasi belajar siswa di sekolah ditentukan oleh faktor-faktor yang bersifat endogen atau internal siswa itu sendiri seperti motivasi belajar siswa dan faktor eksogen atau eksternal siswa seperti peranan guru dalam proses pembelajaran.

Prestasi belajar bukanlah suatu hal yang berdiri sendiri, melainkan mempunyai hubungan dengan beberapa faktor. Pada garis besarnya ada dua faktor yang dapat mempengaruhi yaitu yang bersifat eksternal (pengaruh dari luar diri murid) dan faktor internal (pengaruh dari dalam diri murid itu sendiri). Kedua faktor tersebut dapat dikemukakan secara berurutan sebagai berikut. 


\section{a. Faktor Eksternal}

Yang dimaksud dengan faktor eksternal adalah faktor yang bersumber dari luar seperti:

1) Pengaruh Guru

Menurut penekanan Morison bahwa: "Pada bayangan situasi pada pengajaran sekitar 94\% guru-guru cenderung mengakui bahwa pengajaran yang baik seimbang dengan pengendalian kelas yang baik dan keterampilan guru yang baik/tinggi mempunyai korelasi signifikasi terhadap meningkatnya prestasi belajar siswa yang lebih tinggi terhadap mata pelajaran”. (Marrion And Inure Mc, 1975, p.540)

Pengalaman guru mengajar secara apriasi dapat dikatakan insight yang perlu dikelola guru efektifnya pengajar menuju prestasi belajar siswa yang baik.

2) Pengaruh Materi Pelajaran

Sesuai kurikulum 1975 dalam buku III tentang petunjuk pembuatan Model Satuan Pembelajaran (SP) selalu harus dicantumkan materi pelajaran secara terinci yang diajarkan oleh guru dalam mengajarkan bidang studi. Jadi materi pelajaran tidak kurang pentingnya mempengaruhi prestasi belajar yang baik apabila dalam penentuannya disesuaikan dengan kemampuan siswa.

3) Pengaruh Metode Pembelajaran

Metode yang dipakai itu, makin efektif pencapaian tujuan. Unsur metode mengajar berfungsi sebagai alat (cara) yang digunakan oleh guru dalam mendidik atau mengajar murid yang merupakan kunci atau kemudian dalam mengajar supaya murid-murid dapat berprestasi belajar yang baik. Sebagaimana yang terdapat dalam kurikulum tahun 1975 Sekolah Dasar buku III A2 tentang petunjuk pembuatan satuan pelajaran diisyaratkan pula penentuan metode mengajar yang akan digunakan sesuai dengan tujuan dan materi pelajaran yang akan dicapai. 
4) Pengaruh Situasi Kelas

Ruangan kelas adalah tempat berlangsungnya proses pembelajaran yang perlu mendapat perhatian. Situasi dalam kelas perlu ditata atau diatur supaya menarik murid untuk belajar. Kelas yang pengaturan perabotnya di dalam tidak menarik perhatian, maka anak-anak dalam kegiatan belajar cepat merasa jenuh atau bosan.

\section{b. Faktor-faktor Internal}

Pengaruh yang bersifat internal ini terdiri dari pengaruh-pengaruh antara lain:

1) Pengaruh Faktor Fisik (jasmani)

Kondisi anak yang kurang sehat dapat mengalami kesulitan belajar atau prestasi belajarnya kurang, sedangkan anak-anak yang sehat dan cukup gizi akan tidak mudah lelah dalam belajar. Dia kan penuh perhatian menemukan sendiri hal yang ia pelajari. Dia aktif mendengarkan uraian-uraian . kesehatan jasmani akan mempengaruhi prestasi belajar murid.

2) Pengaruh Faktor Intelegensi

Faktor intelegensi seorang anak yang dimiliki merupakan kapasitet yang potensial, tetapi belum pasti ia dapat melaksanakan kapasitet itu dalam bentuk kongkrit. Begitu pula seseorang anak dapat melaksanakan kapasitet itu dalam bentuk kongkrit tetapi hanya pada sampai tingkat intelegensi yang dimilikinya. Faktor intelegensi merupakan sebab yang dapat mempengaruhi suksesnya anak dalam belajar.

3) Pengaruh Faktor Bakat

Potensi kecakapan yang dibawa sejak lahir umumnya di dalam bidangbidang tertentu sehingga orang yang berbakat belajar sesuai dengan bakatnya sangat mudah ia pelajari dan ia cepat sukses, misalnya anak yang berbakat teknik akan cepat menguasai matematika, fisika, keterampilan dan sebagainya. Sebaliknya yang tidak berbakat akan sulit untuk mempelajari sesuatu yang tidak sesuai dengan bakatnya (Subhan Adi Santoso, 2020, p.168-169). 


\section{Metode Penelitian}

\section{Lokasi Penelitian}

Lokasi penelitian ini dilaksanakan di Madrasah Ibtidaiyah Al-Azhar Serabi Barat Bangkalan.

\section{Metode Penelitian}

Metode yang digunakan dalam penelitian ini adalah metode survei dengan pendekatan korelasional. Survei adalah pengamatan atau penyelidikan yang krisis untuk mendapatkan keterangan yang terang dan baik terhadap suatu persoalan tertentu dan di dalam suatu daerah tertentu (S. Margono, 2004, p.29). Teknik ini di gunakan untuk mengukur kuat lemahnya pelaksanaan hafalan ayat Al-Qur'an dalam meningkatkan prestasi belajar siswa pada mata pelajaran Al-Qur'an hadits.

\section{Variabel Penelitian}

Dalam penelitian ini penulis menguji pengaruh hafalan ayat Al-Qur'an terhadap prestasi belajar al-Qur'an Hadits siswa Madrasah Ibtidaiyah Al-Azhar Serabi Barat Bangkalan.

1. Variabel Bebas (Independent variable) adalah hafalan ayat Al-Qur'an

2. Variabel terikat (dependent Variable) adalah prestasi belajar Al-Qur'an Hadits siswa.

\section{Populasi dan Sampel}

Populasi

Populasi adalah totalitas dari objek penelitian yang dapat berupa manusia, hewan, tumbuh-tumbuhan, dan benda yang mempunyai kesamaan sifat. Populasi merupakan kelompok besar yang menjadi objek penelitian (M. Musfiqon, 2012, p.89). Adapun dalam penelitian ini yang akan menjadi populasi adalah siswa/siswi Madrasah Ibtidaiyah Al-Azhar Serabi Barat Bangkalan yang berjumlah 14 orang. Sampel

Sampel adalah sebagian atau populasi yang diteliti (Suharsimi Arikunto, 2010, p.174). Salah satu syarat yang harus di penuhi di antaranya adalah bahwa sampel harus diambil dari bagian populasi. Dalam penelitian ini sampel yang di 
ambil adalah populasi terjangkau. Berdasarkan survei yang telah dilakukan, di ketahui bahwa jumlah siswa/siswi Madrasah Ibtidaiyah Al-Azhar Serabi Barat Bangkalan kurang dari 100 maka sampel diambil semua.

\section{Teknik Analisis Data}

Teknik analisis data merupakan cara yang digunakan untuk mengurangi keterangan-keterangan atau data yang diperoleh agar data tersebut dapat dipahami bukan pada orang yang mengumpulkan data saja, tapi juga oleh orang lain. Adapun langkah-langkah yang ditempuh adalah sebagai berikut:

\section{Editing}

Dalam pengolahan data yang pertama kali harus dilakukan adalah editing.Ini berarti bahwa semua angket harus diteliti satu persatu tentang kelengkapan dan kebenaran pengisian angket sehingga terhindar dari kekeliruhan dan kesalahan.

Scoring

Setelah melalui tahapan editing, maka penulis memberikan skor terhadap pertanyaan yang ada pada angket.

Adapun pemberian skor untuk tiap-tiap jawaban adalah:

Tabel 1

Skor jawaban angket Hafalan al-Qur'an

\begin{tabular}{|c|c|}
\hline Jawaban & skor \\
\hline Tidak pernah & 1 \\
\hline Kadang-kadang & 2 \\
\hline Sering & 3 \\
\hline Selalu & 4 \\
\hline
\end{tabular}

Setelah itu, untuk mengetahui besar prosentase jawaban angket dari responden, dengan rumus sebagai berikut:

$$
\mathrm{P}=\frac{F}{N} \times 100 \%
$$


Diketahui :

$\mathrm{P} \quad=$ Angka Persentase

$\mathrm{F} \quad=$ Frekuensi yang dicari persentasenya

$\mathrm{N}=$ Number of Cases ( jumlah frekuensi/banyaknya individu)

Ketentuan skala yang yang digunkan adalah:

$100 \%=$ Seluruhnya

$85 \%-99 \%=$ Hampir seluruhnya

$68 \%-84 \%=$ Sebagian besar

$51 \%-67 \%=$ Lebih dari setengah

$50 \%=$ Setengah

$34 \%-49 \%=$ Hampir setengah

$17 \%-33 \%=$ Sebagian kecil

$0 \% \quad$ = tidak ada

Kemudian hasil seluruh jawaban siswa dengan melihat rata-rata jumlah skor, dengan klasifikasi sebagai berikut:

Tabel 2

Klasifikasi Skor Angket hafalan al-Qur'an

\begin{tabular}{|c|c|}
\hline Klasifikasi & Keterangan Jumlah skor jawaban \\
\hline $25-50$ & Rendah \\
\hline $52-75$ & Sedang \\
\hline $76-100$ & Tinggi \\
\hline
\end{tabular}

Selanjutnya adalah perhitungan terhadap hasil skor yang telah ada. Karena penelitian ini adalah untuk melihat apakah ada korelasi antara hafalan al-Qur'an dengan prestasi belajar studi al-Qur'an Hadits siswa, maka yang dipakai adalah rumus "r" product moment (Sugiyono, 2013, p.228). Adapun rumusnya adalah sebagai berikut:

$$
\mathrm{r}=\frac{\mathrm{n}\left(\sum \mathrm{XY}\right)-\left(\sum \mathrm{X}_{1}\right)\left(\sum \mathrm{Y}\right)}{\sqrt{\left\{\mathrm{n}\left(\sum \mathrm{X}_{1}{ }^{2}\right)-\left(\sum \mathrm{X}_{1}\right)^{2}\right\}\left\{\mathrm{n}\left(\sum \mathrm{Y}^{2}\right)-\left(\sum \mathrm{Y}\right)^{2}\right\}}}
$$


Diketahui :

$$
\begin{array}{ll}
\mathrm{r} & =\text { koefisien korelasi } \\
\mathrm{N} & =\text { Number of Cases (jumlah frekuensi/banyaknya individu) } \\
\sum^{\mathrm{XY}} & =\text { Jumlah hasil perkalian antara skor } \mathrm{X} \text { dan } \mathrm{Y} \\
\sum^{\mathrm{X}} & =\text { Jumlah seluruh skor } \mathrm{X} \\
\sum^{\mathrm{Y}} & =\text { Jumlah seluruh skor } \mathrm{Y}
\end{array}
$$

Setelah diperoleh angka indek product moment korelasi "r", maka dilakukan interpretasi data (Sugiyono, 2013, p.228). secara sederhana dengan mencocokan hasil penelitian dengan angka indek korelasi " $r$ " product moment seperti dibawah ini:

Tabel 3

Interpretasi Data korelasi

\begin{tabular}{|c|c|}
\hline Interval Koefisien & Tingkat Hubungan \\
\hline $\mathbf{0 , 0 0}-\mathbf{0 , 1 9 9}$ & Sangat Rendah \\
$\mathbf{0 , 2 0}-\mathbf{0 , 3 9 9}$ & Rendah \\
$\mathbf{0 , 4 0}-\mathbf{0 , 5 9 9}$ & Sedang \\
$\mathbf{0 , 6 0}-\mathbf{0 , 7 9 9}$ & Kuat \\
$\mathbf{0 , 8 0}-\mathbf{1 , 0 0 0}$ & Sangat Kuat \\
\hline
\end{tabular}

\section{Hasil dan Pembahasan}

\section{Hasil}

1. Pengaruh Hafalan Ayat Al-Qur'an Terhadap Prestasi Belajar Siswa Mata Pelajaran Al-Qur'an Hadits

Setelah data-data yang masuk dalam angket diolah melalui editing, maka langkah berikutnya menyajikan data tersebut dalam bentuk table dengan 
mengunakan rumus prosentase. Berikut ini peneliti sajikan hasil prosentase jawaban.

Tabel 4

Apakah Kegiatan Hafalan Al-Qur'an Dapat Menggangu Pelajaran Yang Lain

\begin{tabular}{|c|l|c|c|}
\hline No & Altenatif Jawaban & Frekuensi & Prosentase \\
\hline 1 & a. Selalu & 1 & $7.14 \%$ \\
& b. Sering & 1 & $7.14 \%$ \\
& c. Kadang-kadang & 0 & $0 \%$ \\
& d. Tidak pernah & 12 & $85.71 \%$ \\
\hline \multicolumn{2}{|r|}{ Jumlah } & 14 & $100 \%$ \\
\hline
\end{tabular}

Dari Tabel 4 dapat diketahui bahwa $7.14 \%$ siswa menjawab selalu menganggu pelajaran lain, $7.14 \%$ siswa menjawab sering, $0 \%$ siswa menjawab kadang-kadang, dan $85.71 \%$ siswa menjawab tidak pernah.

Tabel 5

Apakah Tujuan dan Niat Anda Untuk Menghafal Al-Qur'an Selalu Ikhlas

\begin{tabular}{|c|l|c|c|}
\hline No & Altenatif Jawaban & Frekuensi & Prosentase \\
\hline 2 & a. Selalu & 11 & $78.57 \%$ \\
& b. Sering & 0 & $0 \%$ \\
& c. Kadang-kadang & 1 & $7.14 \%$ \\
& d. Tidak pernah & 2 & $14.28 \%$ \\
\hline \multicolumn{2}{|c|}{ Jumlah } & 14 & $100 \%$ \\
\hline
\end{tabular}

Dari Tabel 5 dapat diketahui bahwa $78.57 \%$ siswa menjawab selalu menghafal Al-Qur'an dengan ikhlas, 0\% siswa menjawab sering, 7.14\% siswa menjawab kadang-kadang, dan $14.28 \%$ siswa menjawab tidak pernah.

\section{Tabel 6}


Apakah Anda Merasa Beribadah Ketika Menghafal Al-Qur’an

\begin{tabular}{|c|l|c|c|}
\hline No & Altenatif Jawaban & Frekuensi & Prosentase \\
\hline 3 & a. Selalu & 8 & $57.14 \%$ \\
& b. Sering & 0 & $0 \%$ \\
& c. Kadang-kadang & 3 & $21.41 \%$ \\
& d. Tidak pernah & 3 & $21.42 \%$ \\
\hline \multicolumn{2}{|c|}{ Jumlah } & 14 & $100 \%$ \\
\hline
\end{tabular}

Dari Tabel 6 dapat diketahui bahwa 57.14\% siswa menjawab selalu meras beribadah ketika hafalan Al-Qur'an, 0\% siswa menjawab sering, 21.41\% siswa menjawab kadang-kadang, dan $21.42 \%$ siswa menjawab tidak pernah.

Tabel 7

Apakah Dengan Menghafal Al-Qur'an Anda Merasa Terjauh Dari Sifat Madzmumah Atau Tercela

\begin{tabular}{|c|l|c|c|}
\hline No & Altenatif Jawaban & Frekuensi & Prosentase \\
\hline 4 & a. Selalu & 8 & $57.14 \%$ \\
& b. Sering & 4 & $28.57 \%$ \\
& c. Kadang-kadang & 0 & $0 \%$ \\
& d. Tidak pernah & 2 & $1428 \%$ \\
\hline \multicolumn{2}{|c|}{ Jumlah } & 14 & $100 \%$ \\
\hline
\end{tabular}

Dari Tabel 7 dapat diketahui bahwa 57.14\% siswa menjawab menghafal AlQur'an sering merasa terhindar dari sifat tercela , 28.57\% siswa menjawab sering, $0 \%$ siswa menjawab kadang-kadang, dan $14.28 \%$ siswa menjawab tidak pernah.

Tabel 8

Apakah Anda Selalu Meluangkan Waktu Untuk Menghafal Al-Qur'an Setelah Selesai Sholat 5 Waktu

\begin{tabular}{|l|l|l|l|}
\hline No & Altenatif Jawaban & Frekuensi & Prosentase \\
\hline
\end{tabular}




\begin{tabular}{|c|l|c|c|}
\hline 5 & a. Selalu & 2 & $14.28 \%$ \\
& b. Sering & 1 & $7.14 \%$ \\
& c. Kadang-kadang & 7 & $50 \%$ \\
& d. Tidak pernah & 4 & $28.57 \%$ \\
\hline \multicolumn{2}{|c|}{ Jumlah } & 14 & $100 \%$ \\
\hline
\end{tabular}

Dari Tabel 8 dapat diketahui bahwa $14.28 \%$ siswa menjawab selalu meluangkan waktu untuk menghafal Al-Qur'an setelah selesai sholat 5 waktu 7.14\% siswa menjawab sering, 50\% siswa menjawab kadang-kadang, dan $28.57 \%$ siswa menjawab tidak pernah.

Tabel 9

Apakah Anda Tidak Mesara Jenuh Dalam Menghafal Al-Qur'an

\begin{tabular}{|c|l|c|c|}
\hline No & Altenatif Jawaban & Frekuensi & Prosentase \\
\hline 6 & a. Selalu & 2 & $14.28 \%$ \\
& b. Sering & 2 & $14.28 \%$ \\
& c. Kadang-kadang & 4 & $28.57 \%$ \\
& d. Tidak pernah & 6 & $42.85 \%$ \\
\hline \multicolumn{2}{|c|}{ Jumlah } & 14 & $100 \%$ \\
\hline
\end{tabular}

Dari Tabel 9 dapat diketahui bahwa $14.28 \%$ siswa menjawab selalu tidak merasa jenuh menghafal Al-Qur'an, $14.28 \%$ siswa menjawab sering, $28.57 \%$ siswa menjawab kadang-kadang, dan $42.85 \%$ siswa menjawab tidak pernah

Tabel 10

Apakah Anda Merasa Menghafal Al-Qur'an Itu Penting

\begin{tabular}{|c|l|c|c|}
\hline No & Altenatif Jawaban & Frekuensi & Prosentase \\
\hline 7 & a. Selalu & 13 & $92.85 \%$ \\
& b. Sering & 0 & $0 \%$ \\
& c. Kadang-kadang & 1 & $7.14 \%$ \\
\hline
\end{tabular}




\begin{tabular}{|c|c|c|c|}
\hline & d. Tidak pernah & 0 & $0 \%$ \\
\hline Jumlah & 14 & $100 \%$ \\
\hline
\end{tabular}

Dari Tabel 10 dapat diketahui bahwa $92.85 \%$ siswa menjawab selalu merasa menghafal Al-Qur'an itu penting, 0\% siswa menjawab sering, 7.14\% siswa menjawab kadang-kadang, dan 0\% siswa menjawab tidak pernah.

Tabel 11

Apakah Anda Sering Mengulang Hafalan Al-Qur'an Di Rumah

\begin{tabular}{|c|l|c|c|}
\hline No & Altenatif Jawaban & Frekuensi & Prosentase \\
\hline 8 & a. Selalu & 3 & $21.42 \%$ \\
& b. Sering & 3 & $21.42 \%$ \\
& c. Kadang-kadang & 7 & $50 \%$ \\
& d. Tidak pernah & 1 & $7.14 \%$ \\
\hline \multicolumn{2}{|c|}{ Jumlah } & 14 & $100 \%$ \\
\hline
\end{tabular}

Dari Tabel 11 dapat diketahui bahwa $21.42 \%$ siswa menjawab selalu mengulang hafalan Al-Qur'an dirumah, 21.42\% siswa menjawab sering, 50\% siswa menjawab kadang-kadang, dan 7.14\% siswa menjawab tidak pernah.

Tabel 12

Apakah Orang Tua Anda Mengetahui Perkembangan Hafalan Al-Qur'an Anda

\begin{tabular}{|c|l|c|c|}
\hline No & Altenatif Jawaban & Frekuensi & Prosentase \\
\hline 9 & a. Selalu & 6 & $42.85 \%$ \\
& b. Sering & 1 & $7.14 \%$ \\
& c. Kadang-kadang & 2 & $14.28 \%$ \\
& d. Tidak pernah & 5 & $35.71 \%$ \\
\hline \multicolumn{2}{|c|}{ Jumlah } & 14 & $100 \%$ \\
\hline
\end{tabular}


Dari Tabel 12 dapat diketahui bahwa $42.85 \%$ siswa menjawab Orang tua selalu mengetahui perkembangan hafalan Al-Qur'an, 7.14\% siswa menjawab sering, $14.28 \%$ siswa menjawab kadang-kadang, dan $35.71 \%$ siswa menjawab tidak pernah.

Tabel 13

Apakah dengan menghafal al-Qur'an, anda merasa mempunyai pedoman hidup

\begin{tabular}{|c|l|c|c|}
\hline No & Altenatif Jawaban & Frekuensi & Prosentase \\
\hline 10 & a. Selalu & 9 & $64.28 \%$ \\
& b. Sering & 4 & $28.57 \%$ \\
& c. Kadang-kadang & 0 & $0 \%$ \\
& d. Tidak pernah & 1 & $7.14 \%$ \\
\hline \multicolumn{2}{|c|}{ Jumlah } & 14 & $100 \%$ \\
\hline
\end{tabular}

Dari Tabel 13 dapat diketahui bahwa $64.28 \%$ siswa menjawab dengan menghafal Al-Qur'an selalu merasa mempunyai pedoman hidup, 28.57\% siswa menjawab sering, $0 \%$ siswa menjawab kadang-kadang, dan $7.14 \%$ siswa menjawab tidak pernah.

Tabel 14

Apakah Anda Iri Saat Melihat Hafalan Teman Anda Bertambah

\begin{tabular}{|c|l|c|c|}
\hline No & Altenatif Jawaban & Frekuensi & Prosentase \\
\hline 11 & a. Selalu & 6 & $42.85 \%$ \\
& b. Sering & 2 & $14.28 \%$ \\
& c. Kadang-kadang & 1 & $7.14 \%$ \\
& d. Tidak pernah & 5 & $35.71 \%$ \\
\hline \multicolumn{2}{|c|}{ Jumlah } & 14 & $100 \%$ \\
\hline
\end{tabular}

Dari Tabel 14 dapat diketahui bahwa $42.85 \%$ siswa menjawab selalu merasa iri saat melihat hafalan Al-Qur'an teman bertambah, $14.28 \%$ siswa menjawab 
sering, 7.14\% siswa menjawab kadang-kadang, dan 35.71\% siswa menjawab tidak pernah.

Tabel 15

Apakah Motivasi Belajar Anda Meningkat Setelah Mengikuti Kegiatan Hafalan Al-Qur'an Khususnya Pada Mata Pelajaran Al-Qur'an Hadits

\begin{tabular}{|c|l|c|c|}
\hline No & Altenatif Jawaban & Frekuensi & Prosentase \\
\hline 12 & a. Selalu & 10 & $71.42 \%$ \\
& b. Sering & 1 & $7.14 \%$ \\
& c. Kadang-kadang & 3 & $21.42 \%$ \\
& d. Tidak pernah & 0 & $0 \%$ \\
\hline \multicolumn{2}{|c|}{ Jumlah } & 14 & $100 \%$ \\
\hline
\end{tabular}

Dari Tabel 15 dapat diketahui bahwa $71.42 \%$ siswa menjawab motivasi belajar selalu meningkat setelah mengikuti kegiatan hafalan Al-Qur'an khususnya pada maya pelajaran Al-Qur'an Hadits 7.14\% menjawab sering, 21.42\% siswa menjawab kadang-kadang, dan 0\% siswa menjawab tidak pernah.

Tabel 16

Dalam Menghafal Al-Qur'an, Apakah Anda Selalu Melisankan dan Menghafalkan Dengan Ingatan

\begin{tabular}{|c|l|c|c|}
\hline No & Altenatif Jawaban & Frekuensi & Prosentase \\
\hline 13 & a. Selalu & 7 & $50 \%$ \\
& b. Sering & 1 & $7.14 \%$ \\
& c. Kadang-kadang & 6 & $42.85 \%$ \\
& d. Tidak pernah & 0 & $0 \%$ \\
\hline \multicolumn{2}{|c|}{ Jumlah } & 14 & $100 \%$ \\
\hline
\end{tabular}

Dari Tabel 16 dapat diketahui bahwa 50\% siswa menjawab dalam menghafal Al-Qur'an selalu melisankan dan menghafal dengan ingatan, 7.14\% 
siswa menjawab sering, $42.85 \%$ siswa menjawab kadang-kadang, dan $0 \%$ siswa menjawab tidak pernah.

Tabel 17

Apakah Anda Sudah Menghafal Semua Surat Dalam Al-Qur'an

\begin{tabular}{|c|l|c|c|}
\hline No & Altenatif Jawaban & Frekuensi & Prosentase \\
\hline 14 & a. Selalu & 0 & $0 \%$ \\
& b. Sering & 1 & $7.14 \%$ \\
& c. Kadang-kadang & 7 & $50 \%$ \\
& d. Tidak pernah & 6 & $42.85 \%$ \\
\hline \multicolumn{2}{|r|}{ Jumlah } & 14 & $100 \%$ \\
\hline
\end{tabular}

Dari Tabel 17 dapat diketahui bahwa 0\% siswa menjawab selalu menghafal semua surat dalam Al-Qur'an, 7.14\% siswa menjawab sering, 50\% siswa menjawab kadang-kadang, dan $42.85 \%$ siswa menjawab tidak pernah.

Tabel 18

Sebelum Memulai Hafalan Al-Qur'an, Apakah Anda Memilih-Milih Metode Yang Cocok Terlebih Dahulu

\begin{tabular}{|c|l|c|c|}
\hline No & Altenatif Jawaban & Frekuensi & Prosentase \\
\hline 15 & a. Selalu & 2 & $14.28 \%$ \\
& b. Sering & 2 & $14.28 \%$ \\
& c. Kadang-kadang & 3 & $21.42 \%$ \\
& d. Tidak pernah & 7 & $50 \%$ \\
\hline \multicolumn{2}{|c|}{ Jumlah } & 14 & $100 \%$ \\
\hline
\end{tabular}

Dari Tabel 18 dapat diketahui bahwa $14.28 \%$ siswa menjawab selalu memilih terlebih dahulu metode yang cocok dalam menghafal Al-Qur'an, 14.28\% siswa menjawab sering, $21.42 \%$ siswa menjawab kadang-kadang, dan 50\% siswa menjawab tidak pernah.

\section{Tabel 19}




\section{Apakah Pembimbing Hafalan Al-Qur'an Anda Selalu Memberikan Motivasi Ketika Menyetorkan Hafalan}

\begin{tabular}{|c|l|c|c|}
\hline No & Altenatif Jawaban & Frekuensi & Prosentase \\
\hline 16 & a. Selalu & 9 & $64.28 \%$ \\
& b. Sering & 0 & $0 \%$ \\
& c. Kadang-kadang & 4 & $28.57 \%$ \\
& d. Tidak pernah & 1 & $7.14 \%$ \\
\hline \multicolumn{2}{|c|}{ Jumlah } & 14 & $100 \%$ \\
\hline
\end{tabular}

Dari Tabel 19 dapat diketahui bahwa 64.28\% siswa menjawab pembimbing hafalan al-Qur'an selalu member motivasi ketika menyetorkan hafalan , 0\% siswa menjawab sering, $28.57 \%$ siswa menjawab kadang-kadang, dan $7.14 \%$ siswa menjawab tidak pernah.

Tabel 20

Apakah Anda Selalu Mengikuti Metode Hafalan Al-Qur'an Yang Pembimbing Berikan Pada Anda Ketika Hafalan

\begin{tabular}{|c|l|c|c|}
\hline No & Altenatif Jawaban & Frekuensi & Prosentase \\
\hline 17 & a. Selalu & 7 & $50 \%$ \\
& b. Sering & 1 & $7.14 \%$ \\
& c. Kadang-kadang & 5 & $35.71 \%$ \\
& d. Tidak pernah & 1 & $7.14 \%$ \\
\hline \multicolumn{2}{|c|}{ Jumlah } & 14 & $100 \%$ \\
\hline
\end{tabular}

Dari Tabel 20 dapat diketahui bahwa 50\% siswa menjawab selalu mengikuti metode hafalan al-Qur'an yang pembimbing berikan ketika hafalan, 7.14\% siswa menjawab sering, $35.71 \%$ siswa menjawab kadang-kadang, dan $7.14 \%$ siswa menjawab tidak pernah.

Tabel 21

Apakah Pembimbing Anda Selalu Memperhatikan dan Mengevaluasi Hafalan Al-Qur'an Anda Saat Di Sekolah 


\begin{tabular}{|c|l|c|c|}
\hline No & Altenatif Jawaban & Frekuensi & Prosentase \\
\hline 18 & a. Selalu & 10 & $71.42 \%$ \\
& b. Sering & 2 & $14.28 \%$ \\
& c. Kadang-kadang & 2 & $14.28 \%$ \\
& d. Tidak pernah & 0 & $0 \%$ \\
\hline \multicolumn{2}{|c|}{ Jumlah } & 14 & $100 \%$ \\
\hline
\end{tabular}

Dari Tabel 21 dapat diketahui bahwa 71.28\% siswa menjawab pembimbing selalu memperhatikan dan mengevaluasi hafalan Al-Qur'an saat di sekolah, $14.28 \%$ siswa menjawab sering, $14.28 \%$ siswa menjawab kadangkadang, dan $0 \%$ siswa menjawab tidak pernah.

Tabel 22

Apakah Kegiatan Hafalan Al-Qur'an Membantu Anda Dalam Kegiatan Proses Belajar Di Kelas, Terutama Pada Mata Pelajaran Al-Qur'an Hadits

\begin{tabular}{|c|l|c|c|}
\hline No & Altenatif Jawaban & Frekuensi & Prosentase \\
\hline 19 & a. Selalu & 9 & $62.28 \%$ \\
& b. Sering & 2 & $14.28 \%$ \\
& c. Kadang-kadang & 3 & $21.42 \%$ \\
& d. Tidak pernah & 0 & $0 \%$ \\
\hline \multicolumn{2}{|c|}{ Jumlah } & 14 & $100 \%$ \\
\hline
\end{tabular}

Dari Tabel 22 dapat diketahui bahwa 62.28\% siswa menjawab hafalan AlQur'an dapat membantu dalam proses belajar di kelas, terutama pada mata pelajaran Al-Qur'an Hadits, 14.28\% siswa menjawab sering, 21.42\% siswa menjawab kadang-kadang, dan 0\% siswa menjawab tidak pernah.

Tabel 23

Apakah Anda Selalu Mendapatkan Atau Memperoleh Nilai Yang Baik Dalam Mata Pelajaran Al-Qur'an Hadits Setelah Mengikuti Kegiatan Hafalan Al-Qur'an 


\begin{tabular}{|c|l|c|c|}
\hline No & Altenatif Jawaban & Frekuensi & Prosentase \\
\hline 20 & a. Selalu & 2 & $14.28 \%$ \\
& b. Sering & 0 & $0 \%$ \\
& c. Kadang-kadang & 11 & $78.57 \%$ \\
& d. Tidak pernah & 1 & $7.14 \%$ \\
\hline \multicolumn{2}{|c|}{ Jumlah } & 14 & $100 \%$ \\
\hline
\end{tabular}

Dari Tabel 23 dapat diketahui bahwa $14.28 \%$ siswa menjawab selalu mendapatkan atau memperoleh nilai yang baik dalam mata pelajaran Al-Qur'an hadits setelah mengikuti kegiatan hafalan Al-Qur'an. 0\% siswa menjawab sering, $78.57 \%$ siswa menjawab kadang-kadang, dan $7.14 \%$ siswa menjawab tidak pernah.

Setelah hasil angket dihitung jumlah skor dibagi dengan jumlah responden (777:14), maka hasil yang diperoleh adalah 55.5. dengan demikian, jumlah skor rata-rata tingkat hafalan Al-Qur'an Madrasah Ibtidaiyah Al-Azhar Serabi Barat Bangkalan. adalah cukup baik.

Dari hasil angket diketahui bahwa jumlah skor jawaban siswa dapat diklasifikasikan sebagai berikut:

Tabel 24

Klasifikasi Jumlah Skor Jawaban Siswa Dari Angket Hafalan Al- Qur’an

\begin{tabular}{|c|c|c|}
\hline Klasifikasi & Jumlah siswa & $\begin{array}{c}\text { Keterangan jumlah skor } \\
\text { jawaban }\end{array}$ \\
\hline $25-50$ & 3 siswa & Rendah \\
\hline $51-75$ & 11 siswa & Sedang \\
\hline $76-100$ & - & Tinggi \\
\hline
\end{tabular}


Jadi, tingkat hafalan Al-Qur'an menurut jawaban angket siswa dianggap sedang atau baik, yakni antara 51-75, sebanyak 11siswa.

2. Prestasi Belajar Mata Pelajaran Al-Qur'an Hadits

Prestasi belajar siswa diambil dari daftar nilai siswa pada buku daftar nilai (lagger), prestasi belajar yang diambil oleh penulis adalah nilai raport siswa pada semester genap tahun ajaran 2019/2020 sebagai berikut:

Tabel 25

Daftar nilai siswa pada mata pelajaran Al-Qur'an Hadits semester II

\begin{tabular}{|c|l|c|}
\hline No & \multicolumn{1}{|c|}{ Nama Responden } & Nilai \\
\hline 1 & Luqmanul Hakim Al mauludi & 88 \\
\hline 2 & Panji Niti Kusuma & 75 \\
\hline 3 & Amarchan Fajar Arif Wicaksono & 84 \\
\hline 4 & Anis Nur Hidayah & 90 \\
\hline 5 & Hidayatul Istiqomah & 78 \\
\hline 6 & Adelia Khoirun Nisa & 79 \\
\hline 7 & Bulan Septia Rahmawati & 79 \\
\hline 8 & Denny Eka Saputra & 75 \\
\hline 9 & Lisan Sidqi & 77 \\
\hline 10 & Mahfudhotin Khoiriyah & 87 \\
\hline 11 & Rafilla Azkiya & 76 \\
\hline 12 & Muhammad syahrul Ramadhani Prasetyo & \\
\hline 13 & Nidau Qonitah az zahroiyah & \\
\hline 14 & Sania Sari & \\
\hline & & \\
\hline & & \\
\hline & & \\
\hline
\end{tabular}




\begin{tabular}{|l|c|}
\hline Jumlah & 1147 \\
\hline
\end{tabular}

Jumlah nilai keseluruhan mata pelajaran Al-Qur'an Hadits siswa/siswi Madrasah Ibtidaiyah Al-Azhar Serabi Barat Bangkalan yang diteliti adalah 1147. Setelah jumlah nilai 1147 dibagi dengan jumlah responden yang berjumlah 14 Orang, maka nilai rata-rata siswa/siswi Madrasah Ibtidaiyah Al-Azhar Serabi Barat Bangkalan dalam mata pelajaran Al-Qur'an Hadits adalah 81.92. dengan demikian, nilai rata-rata prestasi belajar siswa Madrasah Ibtidaiyah Al-Azhar Serabi Barat Bangkalan adalah baik. Hasil tersebut bila ditafsirkan sesuai dengan hasil belajar siswa (raport), nilai 70 ke atas berarti lulus atau nilai terlampaui dari KKM nya.

\section{Pembahasan}

Untuk menguji data antara skor angket hafalan ayat Al-Qur'an dan prestasi belajar siswa mata pelajaran Al-Qur'an Hadits, terlebih dahulu dikorelasikan dua variable tersebut, seperti pada tabel di bawah ini:

Tabel 26

Data Variabel X (Hafalan Ayat Al-Qur'an) dan Variabel Y (Prestasi Belajar Siswa)

$\begin{array}{cccccc}\text { No } & \mathbf{X} & \mathbf{Y} & \mathbf{X}^{2} & \mathbf{Y}^{2} & \mathbf{X Y} \\ 1 & 80 & 88 & 6400 & 7744 & 7040 \\ 2 & 78 & 81 & 6084 & 6561 & 6318 \\ 3 & 69 & 75 & 4761 & 5625 & 5175 \\ 4 & 77 & 84 & 5929 & 7056 & 6468 \\ 5 & 80 & 90 & 6400 & 8100 & 7200 \\ 6 & 82 & 78 & 6724 & 6084 & 6396 \\ 7 & 81 & 79 & 6561 & 6241 & 6399\end{array}$




$\begin{array}{cccccc}8 & 77 & 79 & 5929 & 6241 & 6083 \\ 9 & 84 & 75 & 7056 & 5625 & 6300 \\ 10 & 69 & 77 & 4761 & 5929 & 5313 \\ 11 & 82 & 87 & 6724 & 7569 & 7134 \\ 12 & 69 & 76 & 4761 & 5776 & 5244 \\ 13 & 83 & 89 & 6889 & 7921 & 7387 \\ 14 & 81 & 89 & 6561 & 7921 & 7209 \\ \sum & 1092 & 1147 & 78.979 & 86.471 & 82.457\end{array}$

Dalam menghitung korelasinya, penulis menggunakan program SPSS

Tabel 27
Analisa Korelasi Variabel X (Hafalan al Qur'an) dan Variabel Y (Prestasi belajar Siswa)

\begin{tabular}{|ll|r|r|}
\hline \multicolumn{2}{|c|}{ Correlations } \\
\hline Hafalan_Al_Quran & $\begin{array}{c}\text { Hafalan_AN_ } \\
\text { Quran }\end{array}$ & $\begin{array}{c}\text { Prestasi_ } \\
\text { Belaiar }\end{array}$ \\
& Sig. (2-tailed) & 1 & .511 \\
& $\mathrm{~N}$ & 14 & .062 \\
& Pearson Correlation & .511 & 14 \\
\hline Prestasi_Belajar & Sig. (2-tailed) & .062 & 1 \\
& $\mathrm{~N}$ & 14 & 14 \\
\hline
\end{tabular}

Dari Tabel 27 ternyata angka korelasi antara variabel X dan Variabel Y sebesar 0.511. taraf signifikannya sebesar 5\% dilihat dari tabel korelasi product moment. Hal ini menunjukkan keeratan hubungan antara hafalan Al-Qur'an dengan prestasi belajar siswa termasuk kriteria sedang. Sedangkan arah korelasi menunjukkan positif, artinya apabila hafalan ayat Al-Qur'an mengalami peningkatan maka prestasi belajar mengalami peningkatan begitupun sebaliknya. 
Berdasarkan hasil penelitian ini dapat diimplikasikan baik secara teoritis maupun secara praktis. Secara teoritis, seperti yang di kemukakan sebelumnya yaitu bahwa prestasi belajar Al-Qur'an Hadits dapat dipengaruhi oleh kegiatan hafalan ayat Al Qur'an. Hal ini memberikan implikasi bahwa hubungan keduanya terbentuk seperti garis lurus yang saling berhubungan dan bekerja sama, dalam arti jika kegiatan hafalan ayat Al-Qur'an ditingkatkan maka prestasi belajar Al-Qur'an Hadits siswa juga meningkat. Implikasi praktis yang dapat dilakukan adalah upaya peningkatan kegiatan hafalan ayat Al-Qur'an dalam rangka meningkatkan prestasi belajar Al-Qur'an Hadits siswa.

Secara umum dapat digambarkan respon siswa terhadap kegiatan hafalan AlQur'an menunjukkan bahwa respon siswa terhadap kegiatan hafalan Al-Qur'an mencapai rata-rata 55,5 dan termasuk dalam kategori cukup baik.. Hasil pengamatan selama kegiatan hafalan Al-Qur'an menunjukan bahwa terdapat manfaat yang dapat diperoleh siswa selain dapat meningkatkan prestasi belajar Al-Qur'an hadits siswa, diantaranya sebagai sarana menambah ilmu, dapat membantu siswa untuk menjaga hafalannya yang telah dikuasai agar tidak mudah lupa dan lalai, dapat memperbaiki kualitas hafalan, dapat saling memperdengarkan hafalan dan bacaan masing-masing, dapat diamalkan dalam kehidupan sehari-hari. Akan tetapi terhadap faktor kendala atas penentu keberhasilan kegiatan hafalan ayat Al-Qur'an seperti: pengelolahan kelas yang belum optimal, waktu yang disediakan untuk hafalan ayat Al-Qur'an kurang, dan masih rendahnya kemampuan siswa dalam membaca Al Qur'an. Hal ini menyebabkan belum secara keseluruhan kegiatan hafalan ayat Al-Qur'an memberikan kontribusi terhadap prestasi belajar Al-Qur'an Hadits siswa.

\section{Kesimpulan}

Dari hasil penelitian yang telah dilakukan, dapat diambil kesimpulan sebagai berikut:

1. Adanya pengaruh antara hafalan Al-Qur'an dengan prestasi belajar siswa pada bidang studi Al-Quran Hadits di Madrasah Ibtidaiyah Al-Azhar Serabi Barat 
Bangkalan dengan interpretasi Sedang. Dengan angka korelasi antara variabel X dan Variabel Y sebesar 0.511. taraf signifikannya sebesar 5\% dilihat dari table korelasi product moment.

2. Prestasi belajar siswa pada mata pelajaran Al-Qur'an Hadits di Madrasah Ibtidaiyah Al-Azhar Serabi Barat Bangkalan setelah melalui kegiatan hafalan AlQur'an berada pada kategori baik dengan rata-rata 81.92 dari keseluruhan responden

\section{Daftar Rujukan}

Al Mundziri, Imam. 2003. Ringkasan Hadits Shahih Muslim. cetakan kedua. Jakarta: Pustaka Amani.

Arifin, 1994. Ilmu Pendidikan Agama, Jakarta: Bumi Aksara.

Arifin, Zainal. 2008. Metodologi Penelitian Pendidikan, Surabaya: Lentera cendikia

Arifin, Zaenal. 2011. Evaluasi Pembelajaran. Bandung: PT Remaja Rosdakarya

Arifin, Zaenal. 2009. Evaluasi Pembelajaran. Jakarta Pusat: Dirjend. Pendidikan

Agama Islam Departemen Agama RI

Arikunto, Suharsimi. 2010. Prosedur Penelitian Suatu Pendekatan Praktik, Jakarta: Rineka Cipta

Azra, Azyumardi. 2002. Pendidikan Islam: Tradisi dan Modernisasi Menuju Millennium Baru, Jakarta: Logos Wacana Ilmu

Basyir, Abu Umar. 2006. Menjadi Kaya dengan Berdakwah, Solo: Wacana Ilmiah Press

Departemen Pendidikan nasional. 2008. Kamus Besar Bahasa Indonesia Pusat Bahasa.

Edisi keempat. Jakarta: Gramedia Pustaka Utama.

Departemen Agama RI, 2005. Al-Qur'an dan Terjemahan, Bandung: PT. Syamil Cipta Media

Departemen Agama RI, 2003. Kurikulum dan Hasil Belajar, Jakarta:Depag. 
Subhan Adi Santoso

Lutfiah, Fifi. 2011. Disertasi sarjana: "Hubungan antara Hafalan Al-Qur'an dengan Prestasi Belajar Al-Qur'an Hadits siswa MTs. Asy-Syukriyyah Cipondoh Tangerang” Jakarta: UIN Syarif Hidayatullah

Mubarak, Wadi. 2015, Pengaruh Menghafal Al-Quran Terhadap Prestasi Belajar, 'Ulumul Qur'an, (Ed) ,24 (http://'Ulumul Qur'an.comdi akses 20 Mei 2015)

M. Musfiqon, Panduan Lengkap Metodologi Penelitian Pendidikan, Jakarta: Prestasi Pustaka Publisher, 2012

Subhan Adi Santoso, 2020, Media Pembelajaran Pendidikan Agama Islam Era Industri 4.0, Yogyakarta: Deepublish

S. Margono, 2004. Metodologi Penelitian Pendidikan, Jakarta: Rineka Cipta Syah, Muhibbin. 2010. Psikologi Belajar. Jakarta:PT Raja Gravindo Persada Sugiyono, 2013. Statistika Untuk Penelitian, Bandung: Alfabeta

Triyono, Ahmad. 2012. Disertasi sarjana: Pengaruh Pendidikan Al-Qur'an dalam Keluarga Terhadap Prestasi Belajar Al-Qur'an Hadis Siswa Kelas IV MI Darul Hikam Cukilan 01 Kecamatan Suruh Kabupaten Semarang Tahun Pelajaran 2011/2012, Salatiga: STAIN Salatiga 